\title{
THE INCOMPLETE LINGUISTIC FEATURES AND SCHEMATIC STRUCTURE IN EFL UNIVERSITY STUDENTS' NARRATIVE TEXTS
}

\author{
T. Thyrhaya Zein ${ }^{1)}$, T. Silvana Sinar ${ }^{2)}$, Nurlela $^{3)}$, Muhammad Yusuf ${ }^{4)}$ \\ 1) Universitas Sumatera Utara, Medan, Indonesia \\ E-mail: t.thyrhaya@usu.ac.id; tirasinar@gmail.com \\ ${ }^{2)}$ Universitas Sumatera Utara, Medan, Indonesia \\ E-mail: tengkusilvana@usu.ac.id \\ 3) Universitas Sumatera Utara, Medan, Indonesia \\ E-mail: nurlela1904@yahoo.co.id \\ 4) Universitas Sumatera Utara, Medan, Indonesia \\ E-mail:yusufelmahbub@gmail.com
}

\begin{abstract}
This study attempts to investigate the incomplete linguistic features and schematic structure in university students' narrative text. Qualitative content analysis method was utilized as the research design. The instrument of the research is the writing sheet. The data were taken from a narrative text written by 34 university students of second-year English education study program under the theme of folktales from North Sumatera. The data were analyzed by using the transitivity system to identify linguistic features in narrative text. The findings present that there are 4 different titles of folktales found in the data. From the data, it was commonly found that there is an incomplete part of the schematic structure of narrative text written by students namely complication, evaluation, resolution, and coda. In terms of linguistic features, it is discovered that most of the students have difficulties in differing the tense used covering the use of regular and irregular verbs, and the absence of dialogue. Then, the conclusion can be drawn that the incomplete schematic structure and linguistic features exist in university students' narrative text. It is also suggested that students keep practicing to write and lecturers should devote higher attention in teaching this genre so that it is able to be comprehended and properly produced by students.
\end{abstract}

Keywords: linguistic features; schematic structure; narrative; systemic functional

\section{INTRODUCTION}

The capability in producing narrative text is a requirement for English department student because this text always exists in the syllabus. It is also in line with Harmer's statement (2004) clarifying that writing skill should be mastered by students since it is always formed part in the teaching English syllabus. It means that this skill must be taught and applied in the teaching-learning process. It is also one of the hardest skills since it merges many aspects of language such as vocabulary mastery, words-arrangement, grammar proficiency, and constructing a paragraph. Writing is also defined as a medium of producing language which is also problematic for both teachers to teach and students to learn (Ebrahimi \& Ebrahimi, 2012). This skill is oriented to product and that's why when students can't produce a good narrative text, they are unable to pass the course.

Each type of text is unique and has different characteristics (Zein et al., 2017). The fulfillment of lexicogrammatical features, schematic structure, and social function are compulsory in order to produce a good narrative text. If students can consistently use all of the language features and schematic structure, they will produce a good organization of a text. The investigation of the lexicogrammatical stratum of language reveals the kinds of internal patterns of clause structures which are highly favored for interpreting experience (Halliday, 1994). 
The communicative purpose of narrative text is to amuse the readers (Gerot \& Wignell, 1994). Anderson \& Anderson (2004) along with Joyce \& Feez (2000) propose that the structures of narrative include orientation, complication, evaluation, resolution, and coda. Then, Joyce \& Feez (2000) also suggest that narratives have some linguistic features such as specific often individual participants with defined identities, mainly use action verb (material processes), normally use past tense, the use of dialogue, descriptive language, and can be written in the first person (I, we) or third person (he, she, they). This genre is mainly employed to tell legends, folktales, and myths. For example, this text can be used to tell the story of Sampuraga, Sigale-gale, Cinderella, Sangkuriang, the legend of Putri Hijau, the legend of Prambanan temple, and etc.

Systemic Functional Linguistics (SFL) is stressing its study on the language as a source of meaning. It helps us to analyze and explain how meanings are made in everyday linguistic interactions (Tshotsho, 2014). Then, it is also designed to prove analysts with complementary lenses for interpreting language in use (Martin \& White, 2005). It is recognized as a very useful descriptive and interpretive framework for seeing language as a strategic, makingmeaning resource (Eggins, 2004). To sum up, SFL is viewed as the system of meaning and can be used to interpret language in the multi-perspective area.

To explore and analyze linguistic feature, the dominant use of the material process, in narrative text, the transitivity system can be utilized. This system is a general way how the phenomena of the real world are represented as linguistic structures (Gerot \& Wignell, 1994). Transitivity system is the realization of field and part of the experiential function which is discussed in systemic functional linguistics.

There are a number of previous studies focusing on the analysis of lexicogrammatical features and narrative text such as Khamkein (2014), Kurniawan (2016), and Ghani et al. (2017). Khamkein (2014) conducted a study entitled "Linguistic Features of Evaluative Stance: Findings from Research Article Discussions". That study deals with the use of the expression of evaluation in academic discourse, focusing on some communicative strategies for indicating stance. The paramount of understanding the use of stance devices in academics, facilitating a better understanding of novice readers and writers when writing academic productions is highlighted from the findings. Khamkein's research is different from this research in terms of the genre used and also the source of the data. The contribution of this research is the model of analysis and data presentation is adopted. Then, Kurniawan (2016) in his research entitled "An Error Analysis of English Grammar in Writing Narrative Texts at the Faculty of Language and Arts Soegijapranata Catholic University Semarang" deals with grammatical errors made by students in writing narrative texts including their beliefs about how they think of their understanding of grammar elements included in theirs. Kurniawan's research is different from this research since it has a different focus. His research emphasizes on the analysis of linguistic features and schematic structure of the narrative text, not the grammatical errors. Additionally, Ghani et al. (2017) conducted the research dealing with "Linguistic Features of Arabic Textbooks and its Correlation with Text Readability Level in Malaysia". It takes focus on identifying the manner in which linguistic features are used in Arabic texts and the correlation between linguistic features and text readability. This research is different from this research in terms of the source of the data even though it has the same point of discussion in linguistic features aspect. The contribution of this research is the model of analysis in exploring the text is adopted in this research.

In order to pass the course, students of the English department have to master and able to produce narrative text well. Based on the preliminary study conducted at the English department, University of Muhammadiyah Sumatera Utara (UMSU), it is discovered that they are still unable to write this text properly. They made some errors such as tenses, and there is also incomplete lexicogrammatical features such as dialogue, and also schematic structure. The example of an error in using tenses found in the data is presented as the following.

Data 1

"He liked fishing and he always does it if he was bored". (Text 2, the legend of Lake Toba)

"The prince fell in love and want to apply for the princess". (Text 3, the legend of Princess Green)

So, the problem appears in the examples above. Those sentences contain the problem in tenses. The narrative text has a linguistic feature which is the dominant use of past tense since it tells about a past event. The students have a problem in differing whether they use simple present or simple past. That's why the lecturer should know if the text produced by student fulfills the characteristics of the narrative in terms of schematic structure and also linguistic features. These should be solved so that the students are able to write this text well.

Therefore, departing from the problem illustrated in advance, this study is aimed to investigate the incomplete linguistic features and schematic structure in university students' narrative texts. The findings of this research are expected to be beneficial as a reference for teachers and lecturers in teaching writing in Indonesia so that they can provide more attention in order to help the students make a better product in writing specifically narrative text.

\section{LITERATURE REVIEW}

\section{A. Systemic Functional Linguistics}

Language has evolved (tens, hundreds, thousands and even millions of) years in response to the demand of the metafunction. It is accordingly held that the structure of language or the text is determined by the function or purpose set by its speakers in using the language (Saragih, 2016). Eggins (2004) adds that systemic linguists make four main theoretical claims about language: (a) That language use is functional; (b) That its function is to make meaning; (c) That meaning is influenced by social and cultural contexts; and (d) That the process of using language is a semiotic process in which people make meanings by making linguistic choices. 
Additionally, Hallidian systemic functional linguistics treated language as fundamental for construing human experiences and it seeks to explore the working of language within a social context (Naz et al., 2012). That's why SFL also deals with the context.

Language has three main kinds of meanings simultaneously running throughout the whole of language, and in a fundamental respect, they determine the way that language has evolved. It is viewed as a system of meanings that carries different language functions simultaneously (Kurdali, 2012). They are referred to in systemic accounts of grammar as metafunctions (Halliday \& Matthiessen, 2014). There are three metafunctions of language i.e. ideational, interpersonal, and textual function which have the same status and function in social context.

Halliday \& Matthiessen (2014) argue that language provides a theory of human experience, and certain of the resources of the lexicogrammar of every language is dedicated to that function and it is called as an ideational function. The ideational function is distinguished into two components namely experiential and logical function which is also called a clause as representation. A clause has meaning as an exchange, a transaction between speaker and listener; the Subject is the warranty of the exchange. It is the element the speaker makes responsible for the validity of what he is saying (Halliday \& Matthiessen, 2014). It is also known as interpersonal function. The last one is a textual function which is also understood as clause as a message which is realized by theme and rheme. Halliday \& Matthiessen (2014) point out that a clause has meaning as a message, a quantum of information; the Theme is the point of departure for the message. It is the element the speaker selects for 'grounding' what he is going on to say.

\section{B. Transitivity}

One of the aspects of Lexicogrammar is transitivity which is the realization of experiential function functioning as a concrete realization of the register in which it views language as a resource for making meaning. It attempts to describe language in actual use and so focus in on text and their context (Gerot \& Wignell, 1994). Halliday \& Matthiessen (2014) argue that a system of transitivity provides the lexicogrammatical resources for construing a quantum of change in the flow of events as a figure as a configuration of elements centered on a process. Each process type provides its own model or schema for construing a particular domain of experience as a figure of a particular kind. It also deals with the process, participant, and circumstance.

Transitivity is representation in language processes (Kress, 1976 as cited in Nguyen, 2012). It can be concluded that transitivity is the representation of experience in clause through a set of process. The framework of a process involves three main factors: a) the process itself: realized typically by verbal groups; b) participants in the process: realized typically by nominal groups; c) Circumstances associated with the process: realized typically by an adverbial group or prepositional phrase.
The term "process" in transitivity comprises the major and minor process. The material, mental, and relational process are the main types of process in the English transitivity system. Additionally, there are three other processes in the boundaries namely behavioral, verbal, and existential process (Halliday \& Matthiessen, 2014). The types of process are presented in the followings:

Material clauses are clauses of doing-\&-happening: a 'material' clause construes a quantum of change in the flow of events as taking place through some input of energy (Haliday \& Matthiessen, 2014).

The mental process is a process of sensing: Mental process construes a quantum of change in the flow of events taking place in our own consciousness (Halliday \& Matthiessen, 2014). This process may be construed either as flowing from a person's consciousness or as impinging on it. The participant who senses, feels, thinks, wants or perceives is called as Senser and it is always human.

The English system operates with three main types of relation: intensive, possessive, and circumstantial; and each of these comes in two distinct modes of being 'attributive' and 'identifying' (Halliday \& Matthiessen, 2014). The category of relational process covers many different ways in which being can be expressed in English clauses.

Halliday \& Matthiessen (2014) points out that this process describes (typically human) physiological and psychological behavior. The boundaries of behavioral processes are indeterminate. They are partly like the material, and partly like the mental. They are the least distinct of the types of the process because of the unclear definition of their own character. The participant who behaves is the Behaver.

The process of saying contributes to the creation of narrative by making it possible to set up dialogic passages and it covers any kind of symbolic exchange of meaning (Halliday \& Matthiessen, 2014). The verbal process includes not only Sayer but Receiver (the one to whom the process is aimed), Verbiage (content of what is said or the name of the saying), and Target (the thing that is targeted by the process) as well. In reported and quoted sentence are not qualified as verbiage.

This illustrates that something exists or happens. Typically, this process has the verb 'BE'; in this respect also they resemble 'relational clauses'. But there are some verbs that commonly occur are mainly different from either the 'attributive' or the 'identifying' (Halliday \& Matthiessen, 2014). The entity or event that is being said to exist is mentioned as Existent.

The meteorological process is unique in English which has no participant in it (Halliday \& Matthiessen, 2014). It is also located between the 'existential' and the 'material'. These kinds of clauses can only be analyzed through the process only.

\section{Writing}

Along with speaking, writing is also part of productive skill. Nystrand (1989) clarifies that writing is a matter of elaborating text in accordance with what the writer can reasonably assume that the reader knows and expects. It 
means that writing is an activity to share information which is understandable for the readers. Additionally, Chitravelu, et al. (2005) asserts that writing is a system for interpersonal communication using visible signs or graphic symbols on a flat surface such as paper, cloth or even stone slabs. As a conclusion, writing is the way to convey the idea, message, and thought in written form.

Good writing has discovered a combination of words, which allows a person the integrity to dominate his subject with a pattern both fresh and origin (Hyland, 2002). Writing is also used not only to generate ideas but also to scrutinize the ideas and language (Richards \& Renandya, 2002 as cited in Eliya, 2015). The effective way to learn how to write is to go at it as a process. Writing is a complex process with a number of operations going on simultaneously. The steps of writing are planning, drafting, editing, and final version (Harmer, 2004 as cited in Yusuf, 2014).

\section{Narrative Text}

Anderson \& Anderson (1997) as cited in Agusta (2015) say that narrative text is a piece of text which tells a story and in doing so entertains and informs the reader or listener. It is in line with what Gerot \& Wignell (1994) state that narrative text has communicative purpose namely in order to amuse the readers. It can be concluded that Narrative text is used to entertain the readers and listeners.

Joyce \& Feez (2000) also hold that narratives have some linguistic features as listed below:

1) Specific often individual participants with defined identities. Major participants are human, or sometimes animal with the human characteristic.

2) Mainly use action verb (material processes), that describe what happens. This can be explored through transitivity analysis.

3) Normally use the past tense

4) Dialogue often includes and uses a number of saying verb (verbal process) such as said, asked, and replied. The tense may change to the present or future in the dialogue. Sometimes these saying verbs also indicate how something is said.

5) Descriptive language is used to enhance and develop the story by creating an image in the reader's mind.

6) Can be written in the first person (I, we) or the third person (he, she, they).

Anderson \& Anderson (1997) as cited in Agusta (2015) presents the schematic structure of narrative text. They are (1) Orientation (2) Complication. (3) Sequence of events (4) Resolution, and (5) Coda. Additionally, Rustipa (2011) gives a further explanation about the generic structure of the narrative text as the following:

1) Orientation

It is the introduction of the storytelling about the characters, the setting of time and place. The clauses are in simple past form. Temporal conjunctions, individualized participants, material processes are used in this stage.
2) Complication

The complication is the main section of a narrative. It contains events of the story which stimulates the reader to guess what will happen in the story. This complication is realized in simple past mental, material processes, individualized participants.

3) Evaluation

Evaluation presents an appraisal of the crisis. Evaluation is mostly realized in attitudinal lexis.

4) Resolution

The resolution shows how the crisis is resolved. The mental, verbal, material, and simple past processes are used in this stage.

5) Coda

Coda is the concluding stage. The purpose is to make a point about the text as a whole. Coda sometimes conveys comment of the narrator towards the significance of the narrative. Besides material, mental processes, appraisal lexis is also included in the coda.

\section{METHODOLOGY}

Qualitative content analysis was employed as a research method. Singh (2006) states that content analysis, sometimes known as document analysis deals with the systematic examination of current records or documents as sources of data.

The research was conducted at the English education study department of Universitas Muhammadiyah Sumatera Utara, Medan, Indonesia. The number of participants involved as the sample was 34 second-year students. The reason for the selection is they have acquired the materials about narrative text and the method used in teaching writing is a genre-based approach. The source of the data was collected from the narrative text under the theme folktales from North Sumatera which the length of the text is 275-400 words. The main instrument in this research was the researchers themselves and the second instrument was the writing sheets.

The content analysis carried out follows some procedures. The first procedure is data collection. The second procedure is data analysis which concerns the more conventional processes of identification and representation of patterns that are significant to the results of the analysis. The data were analyzed by using some steps proposed by Ezzy (2012) as the followings:

1) Recognizing the segments of the texts.

2) Identifying and analyzing the schematic structure of the text.

3) Identifying and analyzing the lexicogrammatical features of the text.

4) Inference making.

\section{RESULTS AND DISCUSSION}

A. Results

This part illustrates the result of the analysis of and linguistic features and schematic structure of University 
students' narrative text. There are two parts of the result because there were two research questions for this study. Linguistic features and schematic structure analysis are presented successively.

\section{Lexicogrammatical Features Analysis}

There are 4 titles of narrative text found in this study. The titles are "The Legend of Lake Toba", "Putri Hijau", "The Origin of Pond Sampuraga", and "Simalungun". In terms of lexicogrammatical features, it is illustrated that most of the students have difficulty in defining the tense used covering the use of regular and irregular verbs and the missing of dialogue existence. There are 14 students who have a problem with tenses and grammar including the use of past tense, regular and irregular verb, pronoun, misspelling, and also a preposition. The problem in using past tense is presented in the following data.

Data 3:

"Once upon a time, there is a poor man. That lived in the village. One day, he fishing in the river and he got a fish and he brings the fish to his house. It was the biggest catch which he ever had in his life".

(Taken from text 12: Legend of Lake Toba)

From the data above, the student uses 'is' and 'bring' in writing orientation of the narrative text. The correct form that they should have written is 'is' becoming 'was' and 'bring' becoming 'brought'. Then, in terms of pronoun, the writer wrote that while a man should use personal pronoun He.

Joyce \& Feez (2000) also specify that the existence of dialogue in the narrative text is one of the lexicogrammatical features of the text. From the data, it is obviously seen that there are 16 texts do not contain dialogue in the text (text 2 , $5,7,8,14,17,18,20,21,24,25,27,28,29,30$, and 34). It means that students still have a problem in understanding and applying these lexicogrammatical features. The example of the existence of dialogue found in the text is illustrated as the following data.

Data 4.

The girl greeted him nicely. For a moment, Toba was speechless. When he could control his emotion, he asked her, "Who are you? What's your name? Why suddenly are you here?".

"Pardon me if I am surprised you, Mr. Toba. But, you took me here. I was the fish that you caught in the river. Now, I become a human being again. I would like to thank you and I will be your servant to express my thankfulness", Said the woman.

(Taken from text 8: "The Legend of Lake Toba")

Dialogue is used to perform the interaction among characters, and sometimes to indicate the conflict among characters. In the data presented above, it also signals that there is an interaction between Toba and the fish. That is to show that Toba was astonished due to the sudden existence of a woman in his house.

Another linguistic feature of the narrative text is the individual participant with defined identities. It can be seen in the orientation which introduces the characters in the story such as Toba, Putri Hijau, and Sampuraga. Moreover, the students do not have any problem in utilizing material processes as the dominant process in their narrative text. It is proven that 32 students fulfill this requirement in their writing. The example of the use of the material process in the text is presented in the following Table I.

Data 5

TABLE I

The Example of Material Process Realized in The Data

\begin{tabular}{llll}
\hline He & caught & a big golden fish & in his trap \\
actor & material process & Goal & circumstantial \\
\hline
\end{tabular}

The other linguistic features are successfully followed by students in presenting their text namely descriptive language, and written in the first person (I, we) or third person (he, she, they) and those exist in the data.

\section{Schematic Structure Analysis}

Each genre of text requires a schematic structure to organize and show its uniqueness from other texts. The schematic structures of narrative text are orientation, complication, evaluation, resolution, and coda. This must be written in order to show the good structure of narrative text.

From the data, it is found that there are 9 texts $(26.47 \%)$ fulfill all characteristics of schematic structure namely (text $3,4,7,10,12,13,15,16$, and 27). In the orientation part, all students successfully wrote that part and presented it in their writing. It means that the students are able to introduce the characters, the setting of time and place. Then, there are 11 texts $(32.4 \%)$ which do not contain this part i.e. text 8,11 , $14,17,19,20,24,25,26,30$, and 31 . The complication is the main section of a narrative. It presents us that students are lack of capability in illustrating what will happen in the story. The next part is the resolution and evaluation part. There are 14 texts $(41.2 \%)$ do not contain this part namely text 5, 6, 8, 9, 11, 17, 19, 20, 21, 24, 30, 31, 32, and 33 . Evaluation presents an appraisal of crisis and resolution shows how the crisis is resolved. The last part in the schematic structure of the narrative is a coda. This is also comprehended as the concluding stage aiming to make a point about the text as a whole. It sometimes conveys comment of the narrator towards the significance of the narrative. This part only exists in 12 texts $(35.3 \%)$ and not presented in others. The texts which do not contain this part are text $1,2,5,6,8,14,17,18,19,20,21,22,23,24,25,26$, $28,29,30,32,33$, and 34 or about $64.6 \%$.

\section{B. Discussion}

A good organization of the text should fulfill three characteristics, namely (1) social function, (2) linguistic/lexicogrammatical features, and (3) schematic structure of a certain text. From the findings, it is obviously seen that most of the students have difficulty in distinguishing the use of past tense or present tense including regular and irregular verbs, and the missing of dialogue existence. And there is also the problem in spelling found in some data. Due to a high number of percentage of 
incomplete schematic structure, it means that the students are dominantly unable to write a good narrative text.

The finding is also in line with Mulyaningsih's research (2013) which entitled “An Analysis of Students' Ability in Writing Narrative Text: A Case Study at One Public Junior High Schools in Bandung. In this research, she found that the students from lower achiever level need more practice in writing a narrative text specifically in using lexicogrammatical features. She also suggested that students are given "direct telling" (Callahan \& Rothery, 1989 as cited in Emilia, 2010) of lexicogrammatical features of narrative text since many grammatical errors are still found. This "direct telling" technique can be used to strengthen students" understanding about lexicogrammatical features of the narrative text.

Another research which is in line with the findings of this study conducted by Khamkein (2014) conducted a study entitled "Linguistic Features of Evaluative Stance: Findings from Research Article Discussions". He asserted that a better understanding of how scholars use linguistic features or lexical-grammatical features to convey attitudinal or evaluative meanings can enable novice and new scholars and advanced students to enhance their writing skills. Second, the findings could shed some light into the awareness of some linguistic features that can empower learners to become proficient academic readers and/or writers.

In relation to the findings, the implication of this research is the students have not been able to write narrative text properly due to some missing linguistic features and schematic structures. Since schematic structures differ one genre with other genres, it turns to be a serious problem that must be solved by giving extra task and practice.

\section{CONCLUSION AND SUGGESTION}

It is generally discovered that most of the students have difficulties in presenting the lexicogrammatical features in their writing such as the use of past tense or present tense including regular and irregular verbs, and the incomplete part of linguistic features namely dialogue existence. In terms of schematic structure, most students have problems in organizing their text well due to the absence of complication, evaluation, resolution, and code in their narrative texts.

Then, it is also suggested that students keep practicing to write this genre and lecturers should devote higher attention in teaching this genre and it is also possible to provide extra practice for students in writing this text to students so that students can understand and use linguistic features and schematic structure in narrative text properly.

\section{ACKNOWLEDGMENT}

The writers would like to express their gratitude to the Research Institute of Universitas Sumatera Utara for the TALENTA research grant in 2017. Then, the thankfulness is also addressed to English education study program of Universitas Muhammadiyah Sumatera Utara which provided so much help and kindness during the accomplishment of this study.

\section{REFERENCES}

Agusta, D. (2015). Improving Students' Ability in Writing Narrative Texts Using Short Animated Stories at Class VIII C Of SMPN 2 Sanden, Bantul in the Academic Year of 2013/2014. B.A. Thesis. State University of Yogyakarta, Yogyakarta, Indonesia. Unpublished.

Anderson, K. \& Anderson, M. (2004). Text Types in English 2. Malaysia: The Modern Art Production Group.

Chitravelu, N., Sithamparam, S., \& Choon, T. S. (2005). ELT Methodology: Principles and Practices $2^{\text {nd }}$ Edition. Malaysia: Fajar Bekti.

Ebrahimi, S.F., \& Ebrahimi S.J. (2012). Markedness in Writing: A Case of EFL Students. Theory and Practice in Language Studies, 2(4), 773-777.

Eggins, S. (2004). An Introduction to Systemic Functional Linguistics. New York: Continuum.

Eliya, K.R. (2015). Improving Students' Skills of Writing Short Version of Narrative Texts by Using Comic Strips for the Eleventh Grade of Science Class of MAN Yogyakarta II in the Academic Year of 2012/2013. B.A. Thesis. State University of Yogyakarta, Yogyakarta, Indonesia. Unpublished.

Emilia, E. (2010). Teaching Writing: Developing Critical Learners. Bandung: Rizky Press.

Ezzy, D. (2012). Qualitative Analysis: Practice and Innovation. New South Wales: National Library of Australia.

Gerot, L. and Wignel, P. (1994). Making Sense of Functional Grammar. New South Wales: Antipodean Educational Enterprises.

Ghani, K.A., Noh, A.S. \& Nik Yusoff, N.R. (2017). Ciri-Ciri Linguistik dalam Buku Teks Berbahasa Arab dan Hubungannya dengan Tahap Kebolehbacaan Teks di Malaysia. GEMA Online ${ }^{\circledR}$ Journal of Language Studies, 17(3), 152-166.

Halliday, M.A.K. (1994). An Introduction to Functional $\operatorname{Grammar}\left(2^{\text {nd }} e d\right)$. London: Arnold.

Halliday, M.A.K and Matthiessen C.M.I.M. (2014). An Introduction to Functional Grammar (4 ${ }^{\text {rd }}$ ed.). London: Routledge.

Harmer, J. (2004). How to Teach Writing. New York: Pearson Education Limited.

Hyland, K. (2002). Teaching and Researching Writing. Malaysia: Longman.

Joyce, H., \& Feez, S. (2000). Writing Skills: Narrative and Non-fiction Text Types. Sydney: Phoenix Education Pty Ltd.

Khamkein, A. (2014). Linguistic Features of Evaluative Stance: Findings from Research Article Discussion. Indonesian Journal of Applied Linguistics, 4(1), 5469.

Kurdali, B. (2012). Systemic Functional Analysis of EFL University Students' Writing Across Disciplines. GSTF International Journal of Law and Social Sciences (JLSS), 2(1), 289-295.

Kurniawan, I. (2016). An Error Analysis of English Grammar in Writing Narrative Texts at the Faculty of 
Language and Arts Soegijapranata Catholic University Semarang. B.A. Thesis. Soegijapranata Catholic University Semarang, Semarang, Indonesia. Unpublished.

Martin, J.R. \& White, P.R.R. (2005). The language of Evaluation: Appraisal in English. London \& New York: Palgrave Macmillan.

Mulyaningsih, D.U. (2013). An Analysis of Students' Ability in Writing Narrative Text: A Case Study at One Public Junior High Schools in Bandung. B.A. Thesis. Indonesia University of Education, Bandung, Indonesia. Unpublished.

Naz, S., Alvi, S.D., \& Baseer A. (2012). Political Language of Benazir Bhutto: A Transitivity Analysis of Her Speech "Democratization in Pakistan". Interdisciplinary Journal of Contemporary Research in Business, 4(8), 125-141.

Nguyen, H.T. (2012). Transitivity Analysis of "Heroic Mother" by Hoa Pham. International Journal of English Linguistics, 2(4), 85-100.

Nystrand. (1989). Writing English Language Test. New York: Longman.

Rustipa, K. (2011). Features of English Learners' Narratives. Jurnal Ilmiah Dinamika Bahasa dan Budaya, 5(2), 33-44.

Saragih, A. (2016). Empowering Students through Learning English in the Present Context of Indonesia. Paper presented at National Conference on Language and Culture. Medan: University of Sumatera Utara, March.

Singh, Y.K. (2006). Fundamental of Research Methodology and Statistics. New Delhi: New Age International (P) Limited.

Tshotsho, B. (2014). Assessing Students' Academic Writing Using Systemic Functional Linguistics at a University in South Africa. Int J EduSci, 6(3), 425-433.

Yusuf, M. (2014). The Effect of Applying Clustering Technique on the Students Achievement in Writing Descriptive Paragraph. B.A. Thesis. State University of Medan, Medan, Indonesia. Unpublished.

Zein, T.T., Sinar, T.S., \& Nurlela. (2017). Linguistic Features and Local Wisdom Content in EFL Student's Narrative Texts. Proceedings of the International Conference on Teacher Training and Education 2017 (ICTTE 2017), 7 October, Solo, ISSN 2352-5398. 